\title{
FLOOD MAGNITUDE AND FREQUENCY OF EIGHTMILE BRANCH TRIBUTARY AT THE CULVERT ON NEW JERSEY ROUTE 72, AT STAFFORD TOWNSHIP, NEW JERSEY
}

\author{
By Paul Dunne
}

U.S. GEOLOGICAL SURVEY

Open-File Report 95-323

Prepared in cooperation with the NEW JERSEY DEPARTMENT OF TRANSPORTATION 


\section{U.S. DEPARTMENT OF THE INTERIOR}

BRUCE BABBITT, Secretary

U.S. GEOLOGICAL SURVEY

Gordon P. Eaton, Director

For additional information write to:

District Chief U.S Geological Survey Mountain View Office Park 810 Bear Tavern Road, Suite 206 West Trenton, NJ 08628
Copies of this report can be obtained from:

U.S Geological Survey

Earth Science Information Center

Open-File Reports Section

Box 25286, MS 517

Denver Federal Center

Denver, CO 80225 


\section{CONTENTS}

Page

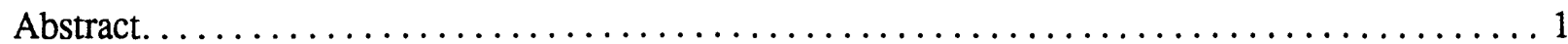

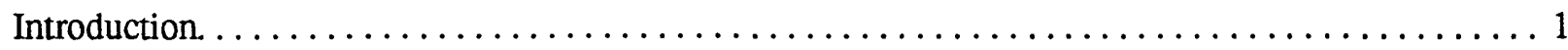

Methods for determining flood magnitude and frequency $\ldots \ldots \ldots \ldots \ldots \ldots \ldots \ldots \ldots \ldots \ldots$

Variation of the transfer method (U.S. Geological Survey) $\ldots \ldots \ldots \ldots \ldots \ldots \ldots \ldots \ldots \ldots \ldots$

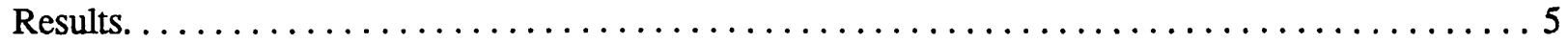

Selected references . . . . . . . . . . . . . . . . . . . . . . . . . . . . . . . 10

\section{ILLUSTRATIONS}

Figure 1. Map showing location of Eightmile Branch tributary at the culvert on New Jersey Route 72 , at Stafford Township, New Jersey .................. 2

2. Graph showing relation of 100 -year peak streamflow determined by using log-Pearson type III analysis of observed data to estimated 100 -year peak streamflow determined by using New Jersey Department of Environmental Protection Special Report 38 method at 18 streamflow and crest-stage gages within a 30-mile radius of Eightmile Branch tributary at the culvert on New Jersey Route 72, at Stafford Township, New Jersey .

\section{TABLES}

Table 1. Explanatory variables for the variation of the U.S. Geological Survey transfer method, pre-development conditions (1950), Eightmile Branch tributary, Stafford

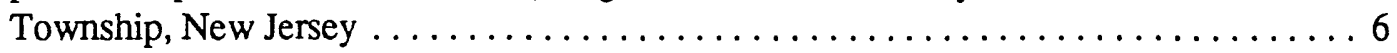

2. Explanatory variables for the variation of the U.S. Geological Survey transfer method, post-development conditions (1990), Eightmile Branch tributary, Stafford Township, New Jersey $\ldots \ldots \ldots \ldots \ldots \ldots \ldots \ldots \ldots \ldots \ldots \ldots$

3. Drainage-basin characteristics and discharge values from log-Pearson type III floodfrequency analysis for streamflow-gaging and crest-stage gaging stations used in the variation of the U.S. Geological Survey transfer method . . . . . . . . . . . 8

4. Flood-magnitude estimates for given flood frequencies using the variation of the U.S. Geological Survey transfer method, Eightmile Branch tributary, Stafford Township, New Jersey 


\section{CONVERSION FACTORS}

Multiply

foot (ft)

mile (mi)

square mile $\left(\mathrm{mi}^{2}\right)$

foot per mile (ft/mi)

cubic foot per second $\left(\mathrm{ft}^{3} / \mathrm{s}\right)$
By

0.3048

1.609

2.590

0.189

0.02832
To obtain

meter

kilometer

square kilometer

meter per kilometer

cubic meter per second 


\title{
FLOOD MAGNITUDE AND FREQUENCY OF EIGHTMILE BRANCH TRIBUTARY AT THE CULVERT ON NEW JERSEY ROUTE 72, AT STAFFORD TOWNSHIP, NEW JERSEY
}

\author{
By Paul Dunne
}

\begin{abstract}
Flood magnitude and frequency of Eightmile Branch tributary at the culvert on New Jersey Route 72, at Stafford Township, New Jersey, were determined by using a variation of the U.S. Geological Survey transfer method. Pre-development (1950) and post-development (1990) drainagebasin characteristics were used with the variation of the transfer method to produce the estimates. Flood magnitude and frequency estimates, as well as drainage-basin characteristics, are included in this report. The 100-year-flood estimates are 50 cubic feet per second for pre-development conditions and 62 cubic feet per second for post-development conditions.
\end{abstract}

\section{INTRODUCTION}

Information on the magnitude and frequency of floods is critical to the planning and design of highway culverts and bridges. Such information is not readily available for many stream crossings in New Jersey. To fulfill this information need, the U.S. Geological Survey, in cooperation with the New Jersey Department of Transportation, began an analysis of flood data from stream-crossing sites on New Jersey streams. This report presents results of the analysis for Eightmile Branch tributary at the culvert on New Jersey Route 72, at Stafford Township, New Jersey. The culvert is located approximately onetenth mile southeast of Neptune Drive at New Jersey Route 72 in Stafford Township, New Jersey (fig. 1). The drainage area above the site is $0.50 \mathrm{mi}^{2}$. A field reconnaissance was performed on September 27,1994 , to verify the locations of the drainage-basin divides and characteristics. Because the direction of storm-sewer drainage in some parts of the basin are uncertain, the calculated drainage area is approximate.

The flood-insurance study for Stafford Township (Federal Emergency Management Agency, 1979) did not include a detailed study of this stream; therefore, flood discharges were not determined previously.

\section{METHODS FOR DETERMINING FLOOD MAGNITUDE AND FREQUENCY}

Various methods for calculating flood magnitude and frequency were given consideration in determining the flood magnitudes that are likely to be exceeded at this site within a given number of years (recurrence interval). The rational method (Chow and others, 1988), New Jersey Department of Environmental Protection (NJDEP) Special Report 38 method (Stankowski, 1974), the U.S. Soil Conservation Service (SCS) Technical Release 55 (TR-55) method (U.S. Soil Conservation Service, 1986), and a variation of the U.S. Geological Survey (USGS) transfer method (New Jersey Department of Environmental Protection, 1993) were all given consideration in determining the flood magnitude and frequency of Eightmile Branch tributary at the culvert on New Jersey Route 72, at Stafford Township, New Jersey. 

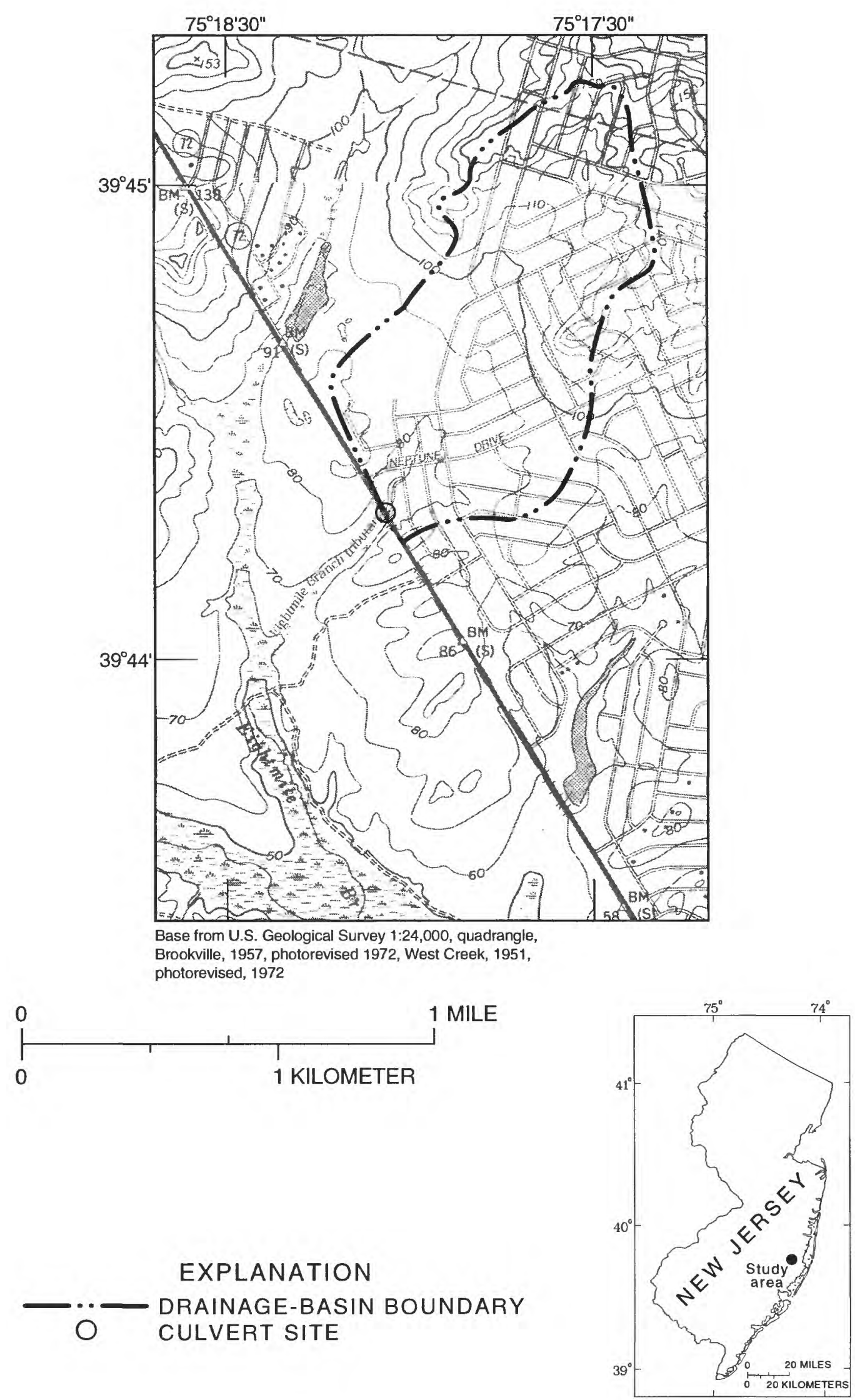

Figure 1. Location of Eightmile Branch tributary at the culvert on New Jersey Route 72, at Stafford Township, New Jersey. 
Special Report 38 typically produces overestimates of flood magnitude for some streamflow gaging stations near the Stafford Township site (Robert D. Schopp, U.S. Geological Survey, oral communication, 1994). Data from eighteen streamflow gages within a 30-mile radius of the culvert site were examined to confirm whether the Special Report 38 method consistently overestimates flood magnitude. Flood magnitude and frequency computed by using the Special Report 38 method were compared with the log-Pearson type III flood-frequency analysis for the 18 streamflow gages performed following documented guidelines (Interagency Advisory Committee on Water Data, 1982). In most cases, the Special Report 38 method overestimated by an average of 3 times the log-Pearson type III data (fig. 2). This bias most likely results from the presence of sandy soils and high-infiltration rates, which are common to the 30-mile radius area (Robert D. Schopp, U.S. Geological Survey, oral communication, 1994). Because the Special Report 38 method produces overestimates for this area, it is probably inappropriate to use this method for this culvert site.

The estimates of the 100 -year flood made for the Route 72 site by using the rational method and the TR-55 method were 2.6 and 3.2 times, respectively, the estimates obtained by using the Special Report 38 method. Therefore, both of these methods also seem inappropriate for use at this culvert site.

A variation of the transfer method was chosen to estimate streamflow at the Eightmile Branch tributary at the culvert on New Jersey Route 72 . Flood data from nearby streamflow or crest-stage gaging stations seem to provide the best estimate of the flood magnitude and frequency that can be expected at the ungaged culvert site, particularly, if drainage area and other basin characteristics are similar.

\section{VARIATION OF THE TRANSFER METHOD (U.S. Geological Survey)}

The relation that is traditionally used (New Jersey Department of Environmental Protection, 1993) to calculate flood estimates is based on a ratio of drainage areas raised to an exponent:

$$
\frac{Q_{P I}}{Q_{P G}}=\left(\frac{A_{P I}}{A_{P G}}\right)^{0.75} \text {, }
$$

where $Q_{P I}$ is the design flood at the point of interest, $Q_{P G}$ is the design flood at the gaged point, $A_{P I}$ is the drainage area at the point of interest, and $A_{P G}$ is the drainage area at the gaged point. This method is recommended for drainage areas that are either less than twice or more than half the drainage area above the gaged point (New Jersey Department of Environmental Protection, 1993).

A variation of the transfer method is used to calculate flood estimates for Eightmile Branch tributary; it is based on a ratio of drainage basin characteristics:

$$
\frac{Q_{P I}}{Q_{P G}}=\frac{A_{i}^{w} S_{i}^{x} S t_{i}^{y} I_{i}^{z}}{A_{g}^{w} S_{g}^{x} S t_{g}^{y} I_{g}^{z}}
$$

where $Q_{P I}$ is the design flood at the point of interest, $Q_{P G}$ is the design flood at the gaged point, $A_{i}$ and $A_{g}$ are the drainage areas, $S_{i}$ and $S_{g}$ are the main-channel slopes, $S_{i}$ and $S t_{g}$ are the surface storage indexes, and $\mathrm{I}_{\mathrm{i}}$ and $\mathrm{I}_{\mathrm{g}}$ are the indexes of manmade impervious cover at the point of interest and at the 


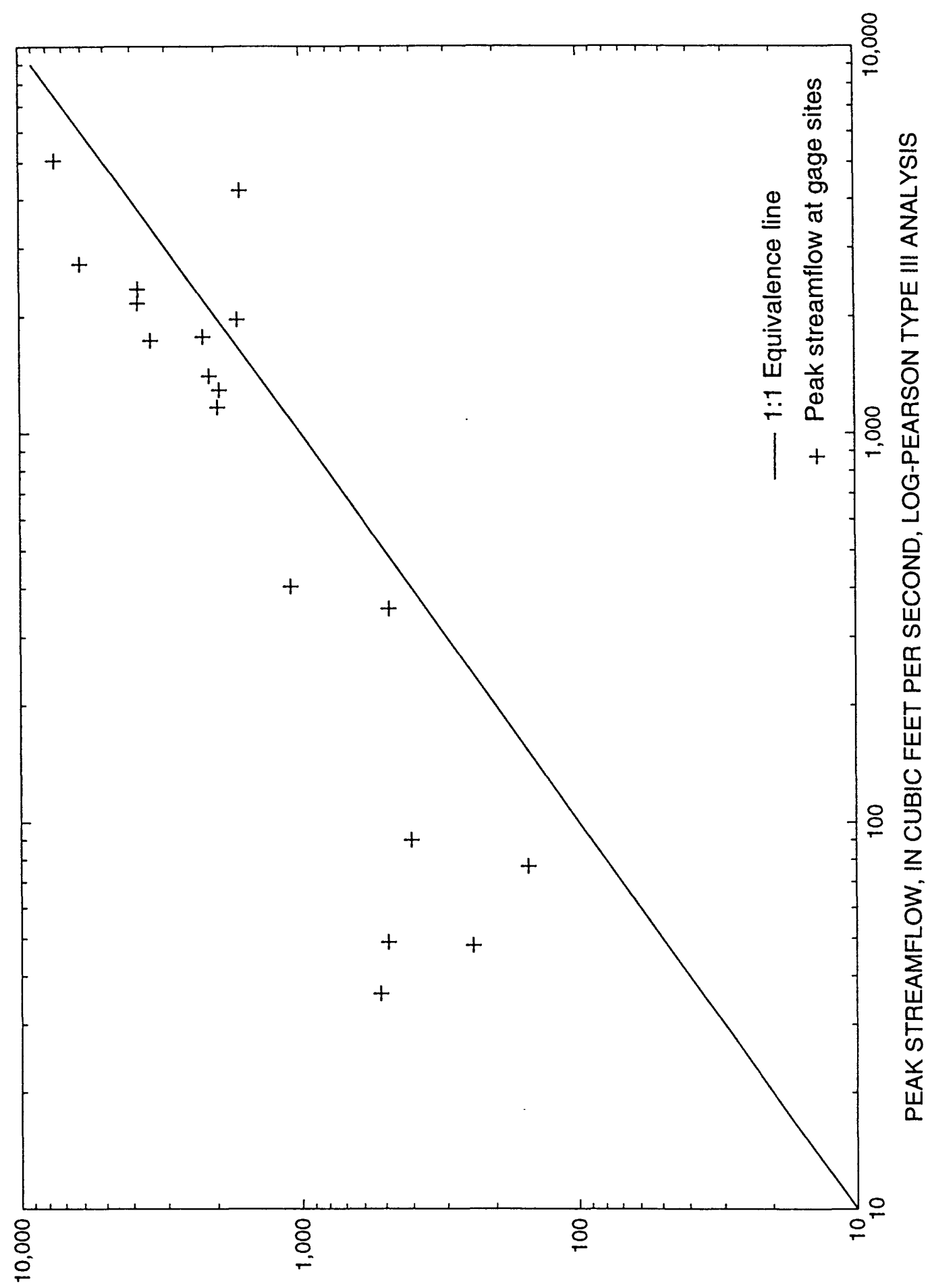
己

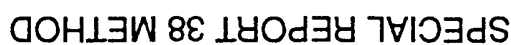

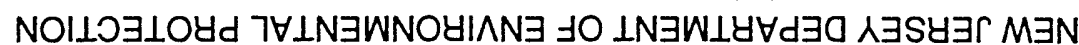

'aNOO $\exists S$ y 
gaged point, respectively. The variables chosen for this method are based on those used in the New Jersey Department of Environmental Protection Special Report 38 method (Stankowski, 1974). The exponents $\mathrm{w}, \mathrm{x}, \mathrm{y}$, and $\mathrm{z}$ vary according to recurrence interval and are the same as those used in the Special Report 38 method. Although the Special Report 38 method overestimates the log-Pearson type III data, a ratio of the drainage-basin characteristics used in the Special Report 38 method allows the characteristics to be considered when adjusting flows from a nearby gaging station to the culvert site without bias from local drainage-basin and geologic conditions.

\section{RESULTS}

Flood data from nearby streamflow or crest-stage gaging stations provide a good indication of the flood magnitude and frequency that can be expected at an ungaged site, particularly when drainage area and other basin characteristics are similar. In this study, estimates obtained by using a variation of the USGS transfer method with data collected at three nearby crest-stage gages (station numbers 01409403,01409375 , and 01409409) and two nearby streamflow-gaging stations (station numbers 01466000 and 01466500 ) were averaged to provide a high degree of accuracy. Of the 18 streamflow and crest-stage gaging stations within a 30-mile radius of the culvert at New Jersey Route 72, Stafford Township, New Jersey, these five stations were chosen because their drainage-basin characteristics are similar to those at the culvert site.

The explanatory variables used in applying the variation of the transfer method for both predevelopment (1950) and post-development (1990) conditions at the culvert site are listed in tables 1 and 2, respectively. Population density, which is related to impervious area, (Stankowski, 1974) was the only variable that changed over time. Table 3 lists drainage-basin characteristics and discharges at gaging stations used in applying the variation of the transfer method. The flood-magnitude and -frequency estimates for both 1950 and 1990 are shown in table 4. The estimate of the 100-year flood discharge at the culvert site for pre-development conditions is $50 \mathrm{ft}^{3} / \mathrm{s}$. The estimate of the 100-year flood discharge at the culvert site for post-development conditions is $62 \mathrm{ft}^{3} / \mathrm{s}$. 
Table 1. Explanatory variables for the variation of the U.S. Geological Survey transfer method, pre-development conditions (1950), Eightmile Branch tributary, Stafford Township, New Jersey

Drainage area: 0.50 square miles

Latitude: $39^{\circ} 44^{\prime} 18^{\prime \prime}$

Longitude: $74^{\circ} 18^{\prime} 03^{\prime \prime}$

Highway: New Jersey Route 72

U.S. Geological Survey 7-1/2-minute quadrangle: West Creek

\begin{tabular}{lll}
\hline \multicolumn{1}{c}{ Variable } & Value & \multicolumn{1}{c}{ Unit } \\
\hline \hline Drainage area & $=0.50$ & (square miles) \\
Main channel slope & $=64.4$ & (feet per mile) \\
Surface storage index & $=1.0$ & \\
Total stream length & $=1.2$ & (miles) \\
Population density (1950) & $=28.3$ & (persons per square mile) \\
Manmade impervious cover index & $=1.4$ & (percent) \\
Lake and swamp area & $=.0$ & (percent) \\
\hline
\end{tabular}


Table 2. Explanatory variables for the variation of the U.S. Geological Survey transfer method, post-development conditions (1990), Eightmile Branch tributary, Stafford Township, New Jersey

Drainage area: 0.50 square miles

Latitude: $39^{\circ} 44^{\prime} 18^{\prime \prime}$

Longitude: $74^{\circ} 18^{\prime} 03^{\prime \prime}$

Highway: New Jersey Route 72

U.S. Geological Survey 7-1/2-minute quadrangle: West Creek

\begin{tabular}{lll}
\hline \multicolumn{1}{c}{ Variable } & Value & \multicolumn{1}{c}{ Unit } \\
\hline Drainage area & $=0.50$ & (square miles) \\
Main channel slope & $=64.4$ & (feet per mile) \\
Surface storage index & $=1.0$ & \\
Total stream length & $=1.2$ & (miles) \\
Population density (1990) & $=260.0$ & (persons per square mile) \\
Manmade impervious cover index & $=1.4$ & (percent) \\
Lake and swamp area & $=.0$ & (percent) \\
\hline
\end{tabular}


Table 3. Drainage-basin characteristics and discharge values from log-Pearson type III floodfrequency analysis for streamflow-gaging and crest-stage gaging stations used in the variation of the U.S. Geological Survey transfer method

[ $Q$, flood-magnitude estimates in cubic feet per second along with number indicating the frequency of the recurrence interval, in years; DA, drainage area, in square miles; $S$, main-channel slope, in feet per mile; St, surface storage index, in percent of drainage area; I, index of manmade impervious cover, in percent of drainage area; $Y R$, years of record; $D$, distance, in miles, of station from flood site]

\begin{tabular}{ccccccccccccc}
\hline $\begin{array}{c}\text { Gaging station } \\
\text { number }\end{array}$ & Q2 & Q5 & Q10 & Q25 & Q50 & Q100 & DA & S & St & I & YR & D \\
\hline \hline Station 01409375 & 32 & 46 & 55 & 69 & 79 & 90 & 3.22 & 12.7 & 5.6 & 19.0 & 13 & 30.0 \\
Station 01409403 & 9.6 & 15 & 20 & 26 & 31 & 36 & 1.03 & 45.7 & 1.0 & 10.3 & 13 & 29.7 \\
Station 01409409 & 12 & 20 & 26 & 34 & 41 & 49 & 3.01 & 14.5 & 3.5 & 15.9 & 11 & 29.5 \\
Station 01466000 & 13 & 22 & 31 & 45 & 59 & 76 & 2.82 & 12.3 & 16.9 & 1.3 & 25 & 16.5 \\
Station 01466500 & 10 & 17 & 23 & 31 & 39 & 48 & 2.35 & 18.4 & 6.1 & 1.2 & 37 & 14.9 \\
\hline
\end{tabular}


Table 4. Flood-magnitude estimates for given flood frequencies using the variation of the U.S. Geological Survey transfer method, Eightmile Branch tributary, Stafford Township, New Jersey

[ Q, flood-magnitude estimates in cubic feet per second along with number indicating the frequency of the recurrence interval, in years; DA, drainage area, in square miles; S, mainchannel slope, in feet per mile; St, surface storage index, in percent of drainage area; I, index of manmade impervious cover, in percent of drainage area]

Drainage area: 0.50 square miles

Latitude: $39^{\circ} 44^{\prime} 18^{\prime \prime}$

Longitude: $74^{\circ} 18^{\prime} 03^{\prime \prime}$

Highway: New Jersey Route 72

U.S. Geological Survey 7-1/2-minute quadrangle: West Creek

\begin{tabular}{lcccccccccc}
\hline & Q2 & Q5 & Q10 & Q25 & Q50 & Q100 & DA & S & St & I \\
\hline \hline Pre-development (1950) & 11 & 17 & 23 & 32 & 39 & 50 & 0.5 & 64.4 & 1.0 & 1.4 \\
Post-development (1990) & 16 & 24 & 31 & 42 & 50 & 62 & 0.5 & 64.4 & 1.0 & 5.7 \\
\hline
\end{tabular}




\section{SELECTED REFERENCES}

Bauersfeld, W.R., Moshinsky, E.W., and Gurney, C.E., 1994, Water resources data, New Jersey, water year 1993, Volume 1. Surface-water data: U.S. Geological Survey Water Data Report NJ-93-1, $503 \mathrm{p}$.

Chow, V.T., Maidment, D.R., and Mays, L.W., 1988, Applied hydrology: New York, McGraw-Hill, $572 \mathrm{p}$.

Federal Emergency Management Agency, 1979, Flood insurance study of Stafford Township, New Jersey: Federal Emergency Management Agency, March 1979, 12 p.

Interagency Advisory Committee on Water Data, 1982, Guidelines for determining flood frequency: Bulletin 17B of the Hydrology Subcommittee, U.S. Geological Survey, Office of Water Data Coordination, Reston, Va., 28 p., 14 app.

New Jersey Department of Environmental Protection, 1993, Technical manual for stream encroachment permits: New Jersey Department of Environmental Protection and Energy, Land Use Regulation Program, Bureau of Inland Regulation, Bureau of Coastal Regulation, May 1993, 100 p., 6 app.

Stankowski, S.J., 1974, Magnitude and frequency of floods in New Jersey with effects of urbanization: New Jersey Department of Environmental Protection, Special Report 38, 46 p.

U.S. Soil Conservation Service, 1986, Urban hydrology for small watersheds: Engineering Division Technical Release 55, Washington, D.C., 162 p. 